\title{
Perencanaan Sistem Plambing Air Bersih Pada Bangunan Kondotel dengan Menggunakan Sistem Gravitasi dan Pompa
}

\author{
Dida Prahara \\ Teknik Lingkungan, Program Sarjana, Universitas TanjungPura, Pontianak. \\ email : dida_enviro11@yahoo.co.id
}

\begin{abstract}
Abstrak
Mengingat pentingnya kebutuhan air bersih pada suatu bangunan maka perlu adanya perencanaan sistem distribusi air bersih ke seluruh bagian yang memerlukan air dengan debit dan tekanan yang sesuai. Dalam perencanaan sistem distribusi air bersih dilakukan perencanaan terhadap volume tangki penampung air dan pompa dengan metode perkiraan penggunaan air berdasarkan jumlah penghuni, sedangkan dalam perencanaan sistem perpipaannya digunakan metode perkiraan kebutuhan air bersih berdasarkan Unit Beban Alat Plambing (UBAP). Dari hasil perhitungan dan analisa diperoleh kebutuhan total air bersih sebesar 245,7 $\mathrm{m}^{3} /$ hari. Sehingga dapat dirancang volume ground reservoir adalah $150 \mathrm{~m}^{3}$ dan $26 \mathrm{~m}^{3}$ untuk roof tank. Pompa yang dipilih adalah dengan head $27 \mathrm{~m}$ dan $66 \mathrm{~m}$.
\end{abstract}

Kata Kunci : air bersih, ground reservoir dan pompa.

\section{Abstract}

Given the importance of clean water needs in a building it is necessary to plan water distribution system to all parts requiring the discharge of water and appropriate pressure. In planning clean water distribution system planning is the volume of the water tank and pump with water use estimation method based on the number of occupants, while the piping system used in the planning method based on the estimated needs clean water Plumbing Equipment Unit Load (PEUL). From the calculation and analysis of the total clean water requirement obtained at $245,7 \mathrm{~m}^{3} /$ day. So it can be designed ground reservoir volume is $150 \mathrm{~m}^{3}$ and $26 \mathrm{~m}^{3}$ for a roof tank. The selected pump is the head $27 \mathrm{~m}$ and $66 \mathrm{~m}$.

Keywords : clean water, ground reservoir and pump.

\section{PENDAHULUAN}

Perkembangan pembangunan gedung pemerintahan dan infrastruktur Kota Pontianak saat ini dilihat dari pembangunan gedung-gedung perkantoran, pendidikan, tempat peribadatan, serta ruang terbuka hijau seperti taman alun-alun kapuas yang terletak di tengah Kota Pontianak. Sedangkan pembangunan gedung-gedung komersial milik swasta dapat dilihat dari pembangunan perumahan dan rumah toko (ruko), serta rumah kantor (rukan) yang dibangun oleh pengembang yang ada di Kota Pontianak. Selain itu pembangunan bangunan komersial saat ini sangat marak dengan pembangunan hotel oleh beberapa investor yang telah berinvestasi di Kota Pontianak.

Perencanaan sistem distribusi air bersih pada sebuah gedung berguna untuk melayani kebutuhan air ke seluruh bagian yang memerlukannya dengan debit dan tekanan yang cukup. Perancangan instalasi penyediaan air bersih dilakukan setelah perencanaan pembangunan dari gedung yang bersangkutan telah ada, karena dari itulah dapat diketahui bagian mana yang memerlukan air dan bagaimana jenis penggunaannya.

Dalam Instalasi air bersih diperlukan sumber air dengan kualitas yang sesuai dengan air bersih dan memiliki tekanan yang cukup pada setiap keluaran (fixture unit), yaitu $\pm 1 \mathrm{bar}\left(1 \mathrm{~kg} / \mathrm{m}^{2}\right)$. Mampu mencukupi air bersih pada saat waktu pemakaian jam puncak, dengan menentukan kapasitas tangki penampung air.

Dalam sistem ini diperlukan perencanaan dengan teknis yang benar (aman untuk keselamatan dan aman untuk jaringan pipa), kebutuhan air terpenuhi, ekonomis (dalam segi 
pendisainan jalur pipa) dan higienis (ditijau dari segi kesehatan). Perencanaan sistem plambing yang baik akan memberikan keamanan dan kenyamanan dalam penggunaan alat plambing terhadap penghuni di gedung tersebut.

Dalam hal ini maka akan ada beberapa permasalahan yang akan dikaji, yaitu:

1. Bagaimana menentukan kebutuhan total penggunaan air di dalam gedung.

2. Menghitung dimensi tangki penampung air.

3. Menentukan diameter pipa yang sesuai dengan debit aliran air.

4. Menentukan daya pompa yang akan digunakan.

Beberapa batasan ditetapkan dalam perencanaan ini meliputi :

1. Instalasi perpipaan yang akan direncanakan adalah pipa yang digunakan khusus untuk air bersih di Kondotel Kawasan Pasar Anggrek Kota Pontianak.

2. Sumber air bersih yang dipakai adalah air dari PDAM yang telah dilakukan pengolahan terlebih dahulu dengan asumsi bahwa kualitas air pengolahan telah memenuhi persyaratan sebagai air konsumsi.

3. Pendistribusian air bersih dari PDAM diasumsikan setiap hari.

4. Kenaikan dan penurunan temperatur air baku dapat diabaikan.

\section{DASAR TEORI}

Dewasa ini sistem penyediaan air bersih yang banyak digunakan dapat dikelompokkan sebagai berikut :

a. Sistem Sambungan Langsung

Dalam sistem ini pipa distribusi dalam gedung langsung terkoneksi dengan pipa utama penyediaan air bersih (misalnya : pipa utama dibawah jalan dari perusahaan air minum). Karena terbatasnya tekanan dalam pipa utama dan dibatasinya ukuran pipa cabang dari pipa utama tersebut, maka sistem ini terutama dapat diterapkan untuk perumahan dan gedung-gedung kecil dan rendah. Ukuran pipa cabang biasanya diatur/ditetapkan oleh perusahaan air minum. Tangki pemanas air biasanya tidak disambung langsung kepada pipa distribusi, dan dibeberapa daerah tidak diizinkan memasang katup gelontor (flush valve).

b. Sistem Tangki Atap

Apabila sistem sambungan langsung oleh berbagai alasan tidak dapat diterapkan, sebagai gantinya banyak sekali digunakan sistem tangki atap, terutama di negara Amerika Serikat dan Jepang. Dalam sistem ini, air ditampung lebih dahulu dalam tangki bawah (dipasang pada lantai terendah bangunan atau dibawah muka tanah) kemudian dipompakan ke suatu tangki atas yang biasanya dipasang diatas atap atau diatas lantai tertinggi bangunan. Sistem tangki atap ini diterapkan dengan alasan-alasan berikut :

- Selama air digunakan, perubahan tekanan yang terjadi pada alat plambing hampir tidak terjadi, perubahan tekanan ini hanyalah akibat muka air dalam tangki atap.

- Sistem pompa yang dinaikkan air tangki atap bekerja otomatis dengan cara yang sangat sederhana sehingga kecil sekali kemungkinan timbulnya kesulitan. Pompa biasanya dijalankan dan dimatikan oleh alat yang mendeteksi muka dalam tangki atap.

- Perawatan tangki atap sangat sederhana jika dibandingkan dengan tangki tekan.

Untuk bangunan-bangunan yang cukup besar, sebaiknya disediakan pompa cadangan untuk menaikkan air ke tangki atap. Pompa cadangan ini dalam keadaan normal biasanya dijalankan bergantian dengan pompa utama, untuk menjaga agar kalau ada kerusakan atau kesulitan maka dapat segera diketahui.

Apabila tekanan air dalam pipa utama cukup besar, air dapat langsung dialirkan ke dalam tangki atap tanpa disimpan dalam tangki bawah dan dipompa. Dalam keadaan demikian ketinggian lantai atas yang dapat dilayani akan tergantung pada besarnya tekanan air dalam pipa utama.

Hal terpenting dalam sistem tangki atap ini adalah menentukan letak "tangki atap" tersebut apakah dipasang di dalam langit-langit, atau di atas atap (misalnya untuk atap dari beton) atau dengan suatu kontruksi menara yang khusus. Penentuan ini harus didasarkan pada jenis alat plambing yang dipasang pada lantai tertinggi bangunan dan tekanan kerja yang tinggi. 
c. Sistem Tangki Tekan

Sistem tangki tekan diterapkan dalam keadaan dimana suatu kondisi tidak dapat digunakan sistem sambungan langsung. Prinsip kerja sistem ini adalah sebagai berikut :

Air yang telah ditampung dalam tangki bawah, dipompakan ke dalam suatu bejana (tangki) tertutup sehingga udara di dalamnya terkompresi. Air dalam tangki tersebut dialirkan ke dalam suatu distribusi bangunan. Pompa bekerja secara otomatis yang diatur oleh suatu detektor tekanan, yang menutup/membuka saklar motor listrik penggerak pompa. Pompa berhenti bekerja kalau tekanan tangki telah mencapai suatu batas minimum yang ditetapkan, daerah fluktuasi tekanan ini biasanya ditetapkan antara 1,0 sampai $1,5 \mathrm{~kg} / \mathrm{cm}^{2}$. Daerah yang makin lebar biasanya baik bagi pompa karena memberikan waktu lebih lama untuk berhenti, tetapi seringkali menimbulkan efek yang negatif pada peralatan plambing.

Dalam sistem ini udara yang terkompresi akan menekan air ke dalam sistem distribusi dan setelah berulang kali mengembang dan terkompresi lama kelamaan akan berkurang, karena larut dalam air atau ikut terbawa keluar tangki. Sistem tangki tekan biasanya dirancang agar volume udara tidak lebih dari $30 \%$ terhadap volume tangki dan $70 \%$ volume tangki berisi air. Bila mula-mula seluruh tangki berisi udara pada tekanan atmosfer, dan bila fluktuasi tekanan antara 1,0 sampai dengan $1,5 \mathrm{~kg} / \mathrm{cm}^{2}$, maka sebenarnya volume efektif air yang mengalir hanyalah sekitar $10 \%$ dari volume tangki. Untuk melayani kebutuhan air yang besar maka akan diperlukan tangki tekan yang besar. Untuk mengatasi hal ini maka tekanan awal udara dalam tangki dibuat lebih besar dari tekanan atmosfer (dengan memasukkan udara kempa ke dalam tangki).

Pada sistem air bersih, penyediaan air harus dapat mencapai daerah distribusi dengan debit, tekanan dan kuantitas yang cukup dengan kualitas air sesuai standar/higienis. Oleh karena itu perencanaan penyediaan air bersih harus dapat memenuhi jumlah yang cukup, higienis, teknis yang optimal dan ekonomis.

Berdasarkan Keputusan Menteri Kesehatan Republik Indonesia nomor 1405/MENKES/SK/XI/2002, bahwa air bersih yaitu air yang dipergunakan untuk keperluan seharihari dan kualitasnya memenuhi persyaratan kesehatan air bersih sesuai dengan peraturan perundang-undangan yang berlaku dan dapat diminum apabila dimasak. Dalam perencanaan sistem penyediaan air bersih suatu bangunan, kebutuhan air bersih tergantung dari fungsi kegunaan bangunan, jumlah peralatan saniter dan jumlah penghuninya. Kebutuhan air bersih dapat dihitung dengan tiga cara yaitu, berdasarkan jumlah penghuni, berdasarkan jenis dan jumlah alat plambing dan berdasarkan beban unit alat plambing. Rumus yang digunakan untuk perhitungan kebutuhan air bersih didalam gedung sebagai berikut :

$\Sigma$ tamu $\quad=\Sigma$ kamar $\times$ BOR $\times$ P (kapasitas kamar max $)$

Pemakaian air pada harian maksimum :

$$
\begin{array}{ll}
\mathrm{Q}_{\mathrm{hm}} & =\mathrm{Q}_{\mathrm{d}} \mathrm{xf}_{\mathrm{hm}} \\
\mathrm{Q}_{\mathrm{hm}} & =\text { pemakaian air pada harian maksimum }\left(\mathrm{m}^{3} / \mathrm{hari}\right) \\
\mathrm{Q}_{\mathrm{d}} & =\text { total kebutuhan pemakaian air }\left(\mathrm{m}^{3}\right) \\
\mathrm{f}_{\mathrm{hm}} & =\text { faktor hari maksimum }: 1,15 \text { sampai } 1,25
\end{array}
$$

Pemakaian air pada jam puncak. :

$$
\begin{aligned}
\mathrm{Q}_{\mathrm{jm}} & =\mathrm{Q}_{\mathrm{hm}} \mathrm{xf}_{\mathrm{jm}} \\
\mathrm{Q}_{\mathrm{jm}} & =\text { jam maksimum } \\
\mathrm{f}_{\mathrm{jm}} & =\text { faktor jam maksimum : } 1,5 \text { sampai } 2,0
\end{aligned}
$$

Untuk merencanakan volume tangki yang berfungsi menyimpan air untuk kebutuhan air bersih dan pemadaman kebakaran dapat dihitung dengan rumus sebagai berikut :

Keterangan :

$$
\mathrm{VR}=\mathrm{Qd}-\mathrm{Qs} \cdot \mathrm{T}
$$

Qd = Jumlah kebutuhan air per hari (m3/hari).

Qs = Kapasitas pipa (m3/hari). 
$\mathrm{T}=$ Rata-rata pemakaian per hari (jam/hari).

VR = Volume tangki air minum (m3).

Kapasitas efektif tangki atas dinyatakan dengan rumus sebagai berikut :

$\mathrm{VE} \quad=(\mathrm{Qp}-\mathrm{Qmax}) \mathrm{T} p+\mathrm{QpuxT} \mathrm{pu}$

Keterangan :

$\mathrm{V}_{\mathrm{E}} \quad=$ Kapasitas efektif tangki atas (liter).

Qp $\quad=$ Kebutuhan puncak (liter/menit).

$\mathrm{Q}_{\max } \quad=$ Kebutuhan jam puncak (liter/menit).

$\mathrm{Q}_{\mathrm{pu}} \quad=$ Kapasitas pompa pengisi (liter/menit).

Tp = Jangka waktu kebutuhan puncak (menit).

Tpu = Jangka waktu kerja pompa pengisi (menit).

Biasanya kapasitas pompa pengisi sebesar $\mathrm{Q}_{\mathrm{pu}}=\mathrm{Q}_{\max }$. Dan air yang diambil dari tangki atas melalui pipa pembagi utama dianggap sebesar $Q_{p}$. Makin dekat $Q p u$ dengan $Q_{p}$ makin kecil ukuran tangki atas. Berlaku ketentuan $\mathrm{Q}_{\mathrm{p}}=\mathrm{Q}_{\mathrm{m}-\max }$ dan $\mathrm{Q}_{\mathrm{pu}}=\mathrm{Q}_{\max }=\mathrm{Q}_{\mathrm{h}-\max }$. Kapasitas suatu pompa tergantung dari debit air yang dialirkan dan tinggi dorong $(\mathrm{H})$. Dari instalasi pompa, menggunakan persamaan energi, maka besarnya head pompa dapat ditentukan dengan persamaan di bawah ini

$$
H p=\frac{P_{2}-P_{1}}{\gamma}+\frac{\left(V_{2}\right)^{2}-\left(V_{1}\right)^{2}}{2 . g}+\left(Z_{2}-Z_{1}\right) \Sigma \mathrm{Hlt}_{1-2}
$$

dimana :

$$
\begin{array}{ll}
H P & =\text { Head total pompa }(\mathrm{m}) \\
\mathrm{P}_{1,2} & =\text { Tekanan fluida pada titik } 1 \mathrm{dan} 2\left(\mathrm{~kg} / \mathrm{m}^{2}\right) \\
\mathrm{V}_{1,2} & =\text { Kecepatan fluida dititik } 1 \text { dan } 2(\mathrm{~m} / \mathrm{dt}) \\
\mathrm{Z} & =\text { Ketinggian }(\mathrm{m}) \\
\mathrm{V} & =\text { Berat jenis fluida }\left(\mathrm{kg} / \mathrm{m}^{3}\right) \\
\mathrm{g} & =\text { Konstanta gravitasi }(9,8 \mathrm{~m} / \mathrm{dt}) \\
\Sigma H t_{1-2} & =\text { Head loos total pipa titik } 1 \text { sampai } 2(\mathrm{~m}) .
\end{array}
$$

\section{METODE PENELITIAN}

Metode suatu perencanaan adalah tata cara atau urutan kerja suatu perhitungan perencanaan untuk mendapatkan hasil Perencanaan instalasi air bersih, air kotor. Metode yang digunakan untuk menyelesaikan perencanaan ini sebagaimana ditunjukkan pada diagram alir, adapun uraian dari metode tersebut dijelaskan sebagai berikut:

\section{Data Debit Air Bersih}

Sumber air bersih yang akan digunakan adalah berasal dari PDAM. Debit yang dihasilkan dari pengaliran PDAM dalam sebesar $8,52 \mathrm{~m}^{3} / \mathrm{jam}$.

\section{Data Survei Pendahuluan}

Dari survei pendahuluan didapatkan data-data tentang posisi shaft pada bangunan gedung, posisi pipa PDAM, dan posisi saluran terbuka gedung.

\section{Metode Perencanaan Instalasi Plambing}

Perencanaan Instalasi air bersih pada pembangunan gedung seperti yang telah disebutkan di atas terdiri dari sembilan lantai, sumber air bersih berasal dari PDAM dengan debit $8,52 \mathrm{~m}^{3} / \mathrm{jam}$. Instalasi air bersih direncanakan dengan menggunakan sistem tangki bawah dan tangki atap. Jalur instalasi mengunakan sistem gravitasi dan pompa. 


\section{Sistem Penyediaan Air Bersih}

Penyediaan air bersih pada Kondotel ini melayani lantai yang berjumlah 9 buah dengan ketinggian gedung sebesar $43 \mathrm{~m}$. Jumlah kamar yang tersedia berjumlah 240 kamar yang terletak dari lantai 3 sampai lantai 9. Luas tanah pada kawasan ini sebesar $130 \mathrm{~m}$ x $95 \mathrm{~m}$ dengan luas bangunan $5.900 \mathrm{~m}^{2}$. Sistem penyediaan air bersih pada Kondotel menggunakan sistem kombinasi yaitu secara gravitasi dan menggunakan pompa penunjang. Dalam perencanaan instalasi perpipaannya digunakan pipa galvanis, begitu pula dengan sambungan pipa yang digunakan terbuat dari bahan yang sama dengan pipa. Pemilihan pipa galvanis ini didasarkan dari keunggulan pipa tersebut yaitu permukaan yang licin, kuat, mudah dibentuk dan tahan karat jika tidak terbuka. Selanjutnya untuk peralatan plambing yang terpasang pada Kondotel dapat dilihat perinciannya pada tabel 1 berikut :

Tabel 1. Peralatan Plambing di Kondotel

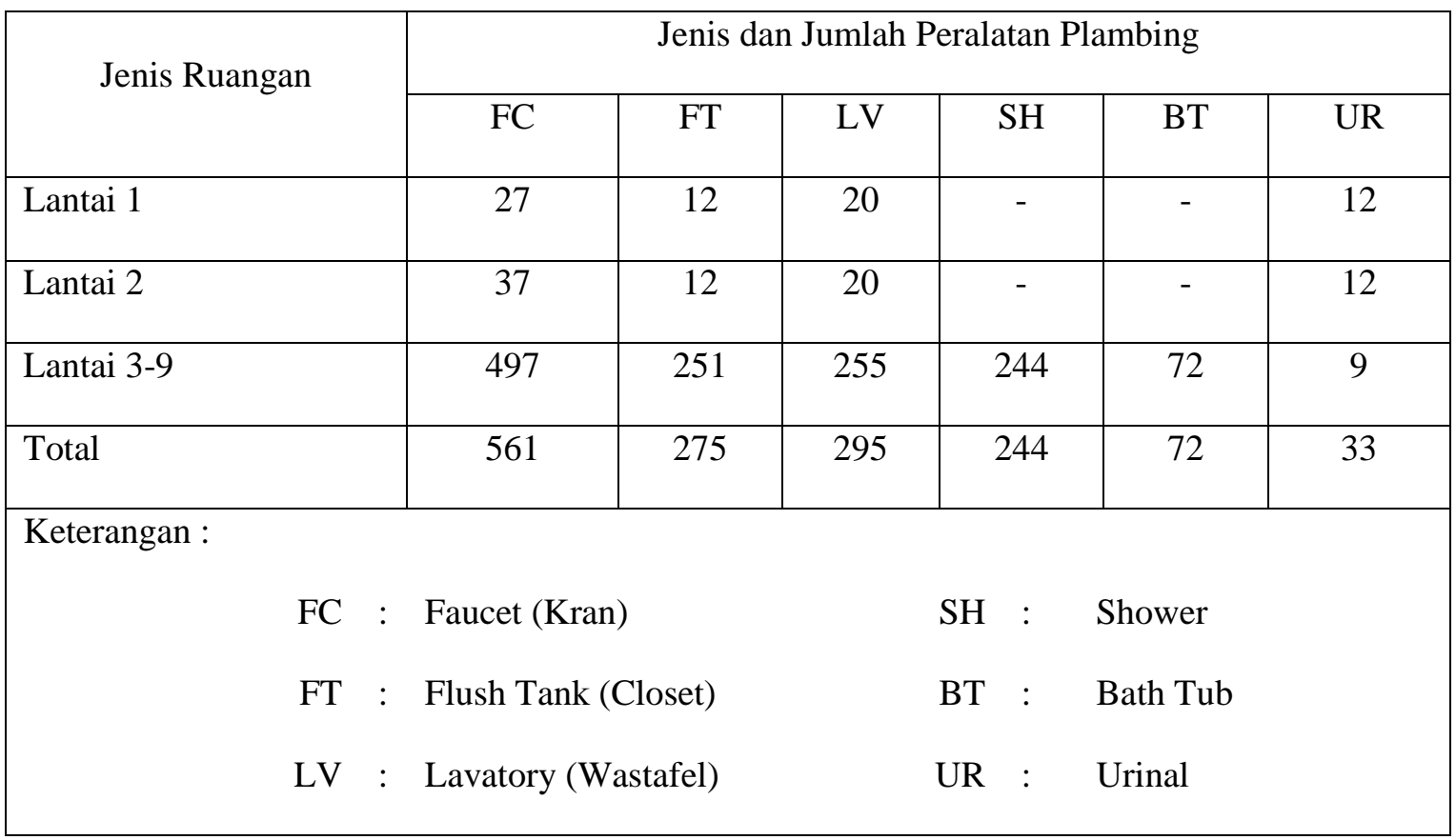

\section{Analisis Perencanaan Instalasi dan Penggambaran.}

Tahap awal perencanaan instalasi air bersih harus memperhatikan kebutuhan air bersih, kapasitas tangki atas, kapasitas tangki bawah dimensi pipa air bersih, spesifikasi pompa, waktu Kerja Pompa. 


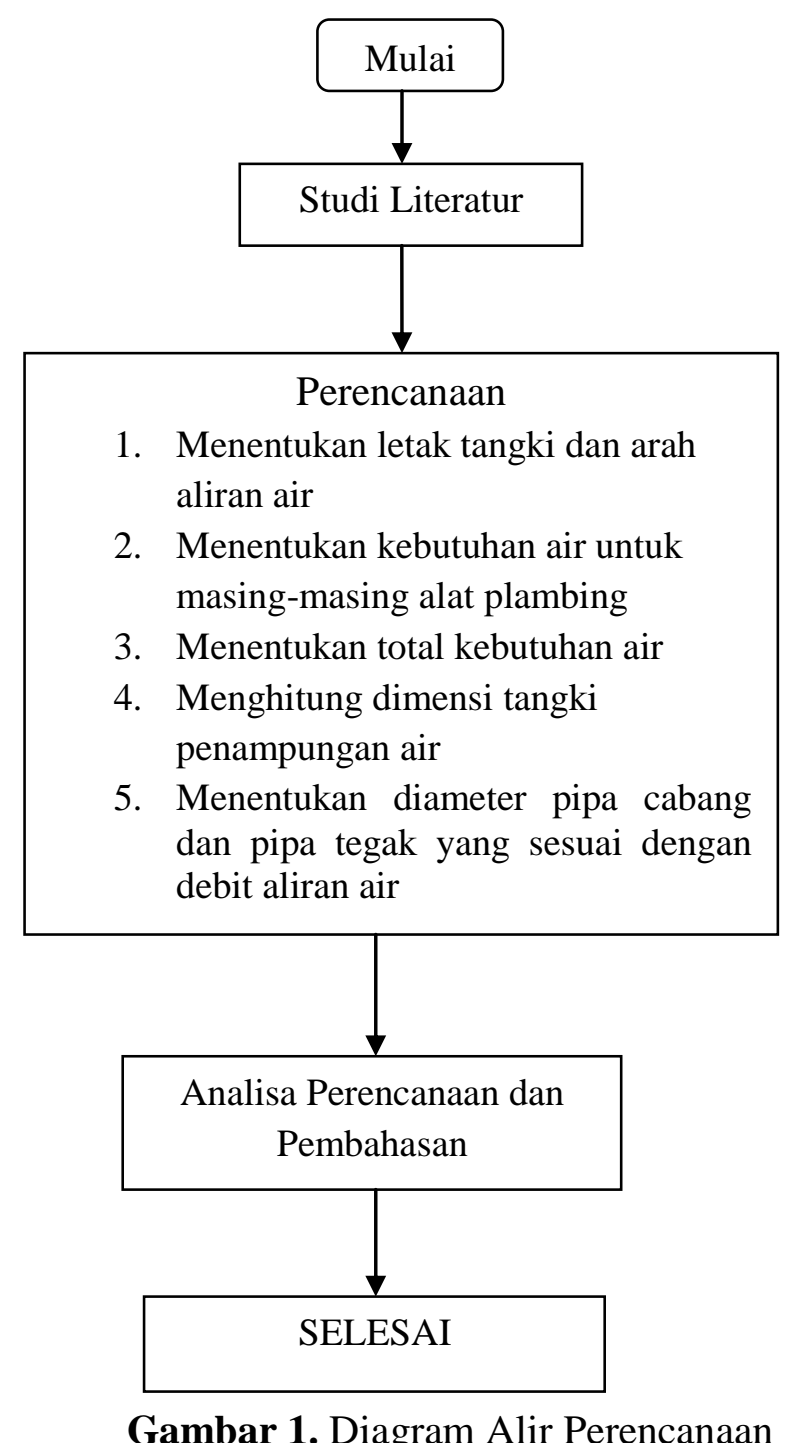

\section{HASIL DAN PEMBAHASAN}

Dalam Perencanaan terdapat sembilan ruang shaft yang digunakan untuk ruang instalasi pipa yang menghubungkan lantai ke-1 sampai lantai ke-9. Tiap Shaft akan melayani beberapa alat saniter dari lantai ke -1 sampai lantai ke-9. Jenis dan jumlah alat saniter berdasarkan shaft yang terdiri dari wc duduk 275 buah, wastafel 295 buah, shower 244 buah, kran 561 buah, urinal 33 buah, dan bath tub 72 buah. 
Tabel 2. Kebutuhan Air Pada Kondotel

\begin{tabular}{|c|c|c|c|}
\hline Jenis Pemakaian & Pemakaian (liter/orang/hari) & $\begin{array}{c}\text { Jumlah Pemakai } \\
\text { (orang) }\end{array}$ & $\begin{array}{c}\text { Kebutuhan Air } \\
\text { (liter/hari) }\end{array}$ \\
\hline Tamu Hotel & 300 & 546 & 163.800 \\
Karyawan & 120 & 160 & 19.200 \\
Restoran & 30 & 200 & 6.000 \\
\hline \multicolumn{2}{|c|}{ Sub Total } & $30 \%$ & 189.000 \\
\hline Lain-lain & make up water AC & 56.700 \\
\hline & Jumlah Total treatment, taman, dll & & 245.700 \\
\hline
\end{tabular}

Sehingga didapat jumlah kebutuhan total air bersih dalam satu hari sebesar 245.700 liter/hari. Kebutuhan air bersih dalam metode ini untuk setiap alat plambing ditetapkan suatu beban unit alat plambing. Sehingga diketahui debit yang dibutuhkan untuk setiap alat plambing. Perhitungan dilakukan pada setiap alat plambing, kemudian dijumlahkan kebutuhan air untuk semua jenis alat plambing pada setiap lantai. Waktu pemakaian alat pelambing dalam satu kali pemakaian untuk kloset 90 detik, wastafel 15 detik, shower 300 detik, kran 80 detik. Kapasitas tangki atas dimaksudkan untuk menampung kebutuhan puncak, dan biasanya disediakan dengan kapasitas cukup untuk jangka waktu kebutuhan puncak tersebut yaitu sekitar 60 menit.

Dalam keadaan tertentu dapat terjadi bahwa kebutuhan puncak di mulai pada saat muka air terendah dalam tangki atas, sehingga perlu perhitungan jumlah air yang dapat di masukkan dalam waktu 10 sampai 15 menit oleh pompa. Debit jam maksimum yang mungkin terjadi pada lantai 3 sampai lantai ke 9 sebesar $(\mathrm{Qjm})=7,1$ liter/detik dan $\left(\mathrm{f}_{\mathrm{jm}}\right)=2$. Dari data-data hasil perhitungan diatas, maka dapat ditentukan kapasitas tangki atas adalah $26 \mathrm{~m}^{3}$. Besarnya kapasitas tangki bawah ditentukan oleh jumlah kebutuhan air bersih sehari di dalam gedung, kapasitas persediaan/sumber air bersih dan rata-rata pemakaian air pada harian maksimum. Dari perhitungan kebutuhan air bersih diketahui kebutuhan total air bersih pada harian maksimum adalah sebesar $306,72 \mathrm{~m}^{3} /$ hari. Sumber air bersih direncanakan berasal dari PDAM dengan debit $8,52 \mathrm{~m}^{3} / \mathrm{jam}$. Jangka waaktu pemakaian air selama 24 jam/hari. sehingga kapasitas tangki bawah dapar dihitung mencapai 150 $\mathrm{m}^{3}$. Volume tangki bawah ini juga mencakup unutk kebutuhan air untuk sistem pemadam kebakaran.

\subsection{Dimensi Pipa Air Bersih}

Langkah-langkah penentuan dimensi pipa air bersih sebelum dikoreksi adalah sebagai berikut :

1. Menentukan jenis pipa.

Pada perencanaan ini jenis pipa yang digunakan untuk instalasi air bersih adalah pipa galvanis.

2. Menentukan beban unit alat plambing (BW).

3. Menentukan debit normal (Q) dari instalasi pipa air bersih. 
4. Total debit $(\mathrm{Q})$ adalah debit dari hasil debit yang mungkin terjadi pada setiap pipa $=$ 0,1 liter/detik,0,2 liter/detik dan 0,24 ltr/detik.

5. Panjang pipa (L) adalah hasil pengukuran panjang pipa pada gambar 4.1 isometri instalasi pipa air bersih lantai 1 .

6. Diameter pipa (Ø) sebelum dikoreksi dapat ditentukan dari Pipa 1 beban unit alat plambing $=1$, maka DN (Diameter Nominal) pipa $1=15 \mathrm{~mm}$ atau $1 / 2$ inchi. Pipa 3 beban unit alat plambing $=2$, maka DN (Diameter Nominal) pipa $1=15 \mathrm{~mm}$ atau $1 / 2$ inchi. Pipa 5 beban unit alat plambing $=3$, maka DN (Diameter Nominal) pipa $1=15 \mathrm{~mm}$ atau $1 / 2$ inchi.

7. Diameter terkecil yang digunkan sebesar $1 / 2$ inchi dan yang terbesar adalah 7 inchi.

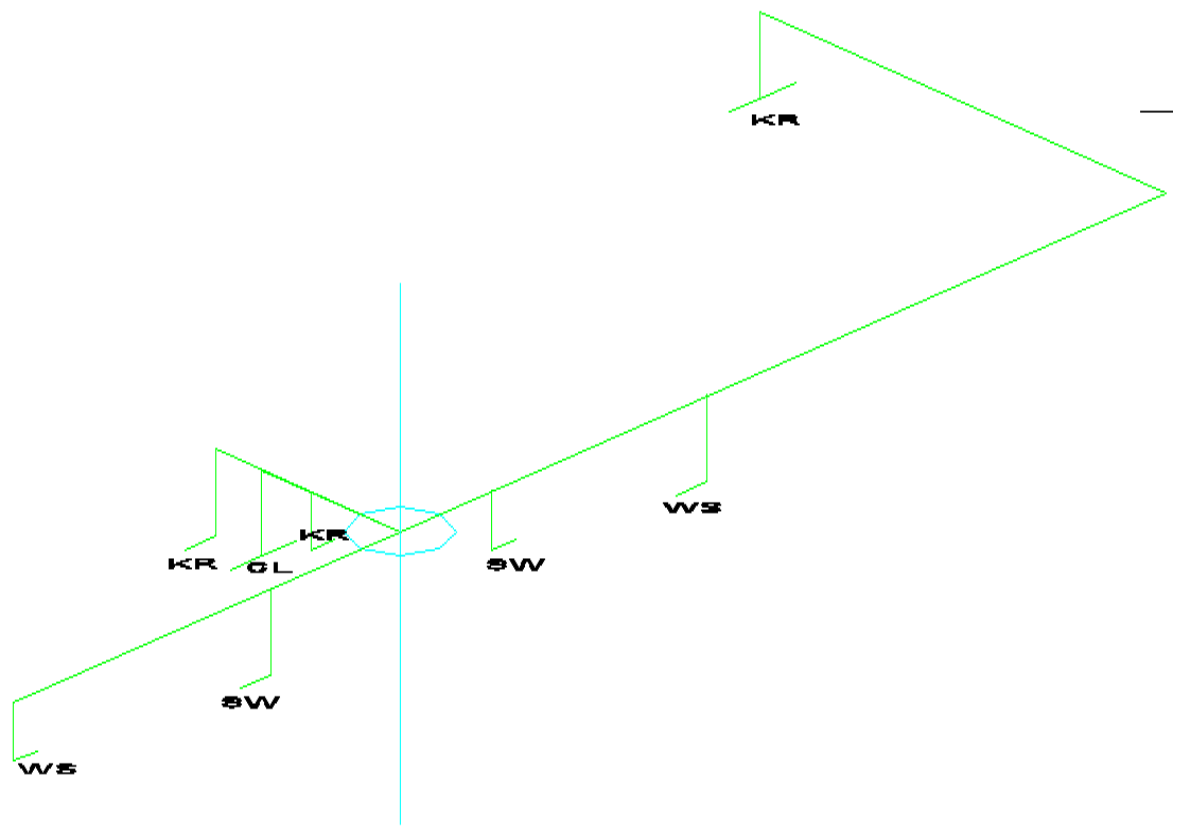

Gambar 2. Isometri instalasi pipa air bersih pada bagian kamar.

\subsection{Pompa booster.}

Pompa booster adalah pompa yang menyalurkan air dari tangki bawah ke fixture unit alat saniter.

1. Debit pompa booster.

Debit (Q) pompa booster dapat diketahui dari perhitungan kapasitas tangki bawah tentang debit puncak yang terjadi bila seluruh alat saniter hidup bersamaan pada lantai 1 sampai 4, dengan debit yang terjadi sebesar $20,59 \mathrm{~m}^{3} / \mathrm{jam}$ dan head pompa sebesar $27 \mathrm{~m}$. 
2. Debit pompa pengisian.

Debit (Q) pompa pengisian dapat diketahui dari perhitungan kapasitas tangki atas tentang debit puncak yang terjadi bila seluruh alat saniter hidup bersamaan pada lantai 3 sampai 9, dengan debit yang terjadi sebesar $20,59 \mathrm{~m}^{3} / \mathrm{jam}$ dan head pompa sebesar $66 \mathrm{~m}$.

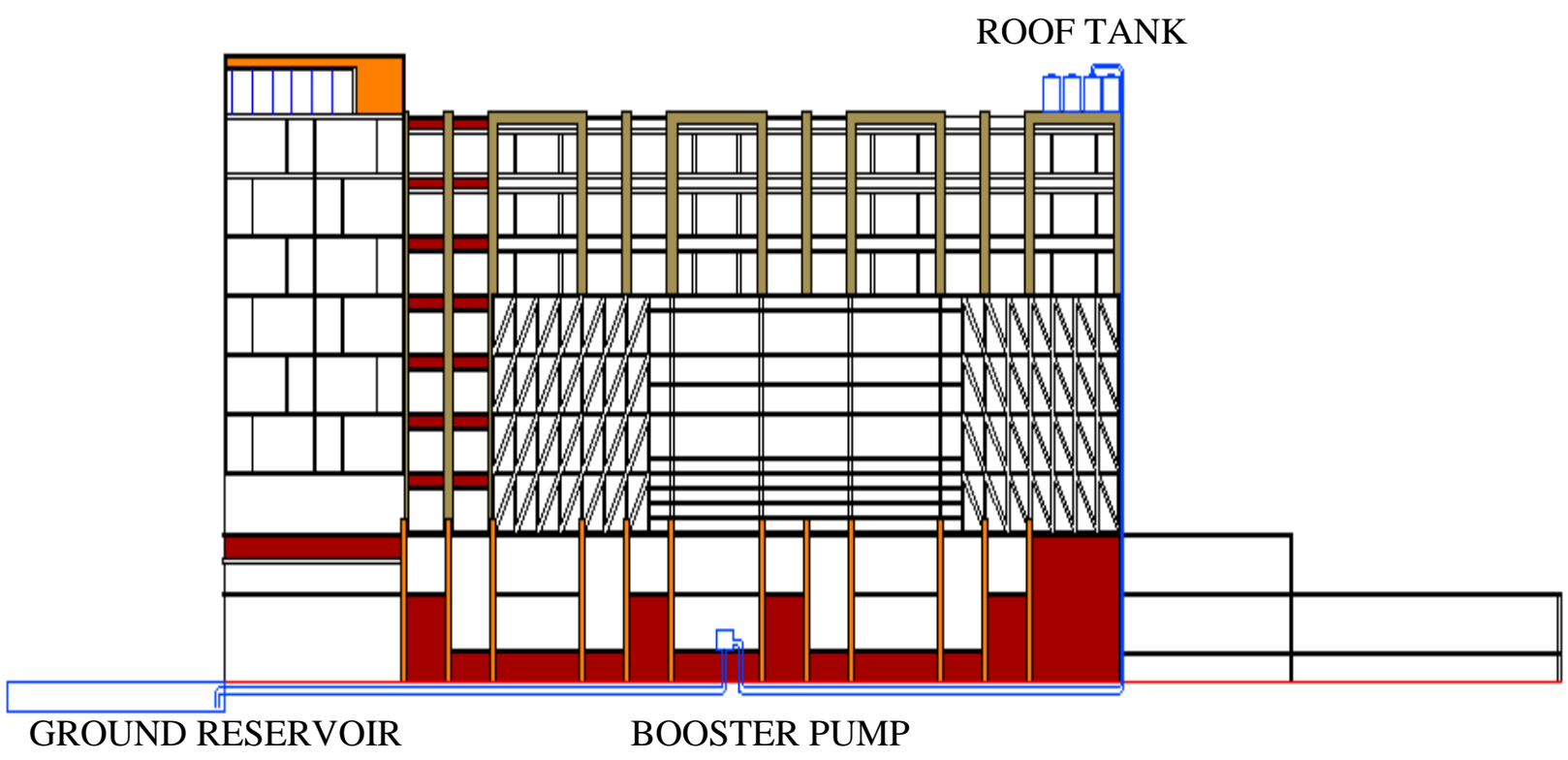

Gambar 3. Perletakkan Pompa dan Roof Tank

\section{Kesimpulan}

Dari analisa Perencanaan Sistem Plambing Air Bersih Pada Bangunan Kondotel dengan menggunakan Sistem Gravitasi dan Pompa diperoleh beberapa kesimpulan sebagai berikut:

1. Total penggunaan air bersih pada Kondotel Kawasan Pasar Anggrek ini sebesar 245.700 lt/hari.

2. Dimensi tangki bawah penampung air bersih sebesar $150 \mathrm{~m}^{3}$ dan tangki atas penampung air bersih sebesar $26 \mathrm{~m}^{3}$.

3. Diameter pipa yang terkecil digunakan dalam sistem pendistribusian air bersih pada bangunan ini adalah $1 / 2$ inc dan yang terbesar adalah 7 inc.

4. Head pompa untuk pendistribusian air dari lantai 1 sampai lantai 4 bagian belakang sebesar $27 \mathrm{~m}$ dan Head pompa untuk pendistribusian air dari lantai 3 bagian depan sampai lantai 9 sebesar 66 $\mathrm{m}$.

\section{Ucapan Terimakasih}

Ucapan terima kasih sebesar-besarnya penulis sampaikan kepada seluruh dosen pengajar Program Studi Teknik Lingkungan Fakultas Teknik UNTAN, terutama kepada dosen pembimbing penulis Winardi Yusuf, ST. MT dan Eko Yulianto, ST. MT serta dosen penguji Dr. Ir. Hj. Kartini, MT dan Ir. H. Nasrullah Chatib, MT atas bimbingan, arahan, kritik dan saran yang telah diberikan sehingga proses perencanaan hingga penulisan jurnal ini dapat penulis selesaikan dengan baik. Semoga hasil perencanaan dan jurnal ini dapat memberikan manfaat bagi masyarakat dan ilmu pengetahuan. Terima Kasih 


\section{DAFTAR PUSTAKA}

[1] Juwana S, Jimmy. 2005. Sistem Bangunan Tinggi. Jakarta : PT. Erlangga

[2] Keputusan Menteri Kesehatan Republik Indonesia, Nomor 1405/Menkes/sk/XI/2002. Persyaratan Kesehatan Lingkungan Kerja Perkantoran dan Industri.

[3] Sofyan M. Noerbambang, Takeo Morimura. 1996. Perancangan dan Pemeliharaan Sistem Plambing. Tokyo : Association for International Technical Promotion.

[4] Sulthony, Fiqri. 2013. Kondotel di Kota Pontianak di Wilayah Pontianak Timur.

[5] Taufan, Muhammad. 2011. Engineering Building Info. Jakarta : PT.Wijaya Nusantara. 